\title{
TRAFFIC GROWTH RATE ESTIMATION USING TRANSPORT DEMAND ELASTICITY METHOD: A CASE STUDY FOR NATIONAL HIGHWAY-63
}

\author{
Hemanth. M Kamplimath ${ }^{1}$, Varuna. $M^{2}$, Vijay Kumar ${ }^{3}$, Yashas Bhargav ${ }^{4}$ \\ ${ }^{1}$ Post Graduate Student, Highway Technology, ${ }^{2}$ Assistant Professor, Dept of Civil Engg, R.V.C.E, Bangalore \\ ${ }^{3}$ Senior Highway Engineer, ${ }^{4}$ Assistant Traffic Engineer, URS Scott Wilson, Bangalore \\ hemanth.kamplimath@gmail.com,varun.m07@gmail.com,vijayakumarsagar@yahoo.com,yashasb3@gmail.com
}

\begin{abstract}
With the recent thrust on improving and developing highways for boosting National Economy, the importance of Traffic Demand Forecasting $(T D F)$ has increased significantly as the forecasted traffic volume contributes substantially in engineering design, economic and financial liabilities of highway improvement projects. Therefore, estimation of traffic growth rates and the related issues concerned primarily to improve the rationality of traffic forecast is of prime importance. In the present Paper, the complete process of Traffic Growth Estimation by Transport Demand Elasticity Method even when available data is inaccurate or even missing, merits and demerits of various methods of obtaining traffic growth factors and critical issues associated in the process have been addressed and demonstrated through a case study. It has been revealed that with the constraints of availability of proper data and fluctuation of developing economy, the task of Traffic Growth Estimation could be quite subjective and approximate. Different approaches and necessary considerations for improving the rationality of traffic growth rate have also been addressed in the paper.
\end{abstract}

Keywords: Traffic Volume, Seasonal Correction Factors, Project Influence, Demand Elasticity, Traffic Demand Forecasting, Traffic Growth Rates.

\section{INTRODUCTION}

The objective of this study is to estimate traffic growth using transport demand elasticity method and to compare how different these values are from the vehicle registration data. In this present study, an attempt has been made to analyze the O-D data for passenger vehicles (cars \& buses) and goods vehicle (trucks) collected by roadside interview method. The passenger characteristics such as average occupancy by mode, trip length, frequency and freight characteristics are analyzed and tabulated. The influence factors of various zones were found out. Socio-economic data viz -Per capita income and Net State Domestic Product, demographic data such as Population and registration of vehicle data of different states influencing the study stretch were collected from statistical data sources. The relationship between annual growths of vehicles in percentage over number of years is established.

To determine elasticity values, the regression analysis is carried out between socio economic variables growth index and vehicle growth index. The elasticity values for the future years are calculated based on the growth trend of vehicles.

\section{STUDY AREA CHARACTERISTICS}

The Project stretch is a part of NH-63 in the state of Karnataka which runs from east to west connecting Karnataka to Andhra Pradesh. The total length of NH-63 is about $432 \mathrm{~km}$, out of which $370 \mathrm{~km}$ runs in Karnataka State and about $55.4 \mathrm{~km}$ runs in Andhra Pradesh.

This case study deals with Hubli - Hospet stretch of NH-63. The project stretch, starts at km $132+000$ of NH-63 at junction with NH-4 Hubli-Dharwad bypass and ends at km 268+700 at junction of NH-63 and NH-13, Hitnal Junction.

\section{DATA COLLECTION}

For the purpose of forecasting traffic on the study stretch, several primary and secondary data were collected as mentioned below.

\subsection{Primary Data}

On the basis of reconnaissance survey and as per the recommendations of IRC, the project stretch was divided into two homogenous sections and suitable location for each section was strategically selected. The various traffic surveys carried out were: 
- 7-day Continuous Traffic Volume Count

- 24 hour Origin and Destination Studies

Strict adherence to IRC codes and manuals were followed for the traffic surveys carried out.

\section{Secondary Data:}

- Fuel sales data along the study stretch

- Past data on traffic volume on the study stretch

- Previous year's vehicle registration data of Karnataka State
- Previous year's data on Per capita Income, Net State Domestic Product (NSDP), Population data of all the states influencing the project corridor and the National Average.

\section{ESTIMATION OF AVERAGE DAILY TRAFFIC} (ADT) AND ANNUAL AVERAGE DAILY TRAFFIC (AADT)

Table 1 showing Average Daily Traffic

\begin{tabular}{|l|l|l|l|l|l|l|}
\hline Survey Location & \multicolumn{4}{|l}{ Nalavadi -159.500 } & \multicolumn{2}{l|}{ Hallikeri-221.400 } \\
\hline Vehicle Category & $\begin{array}{l}\text { ADT } \\
\text { Vehicles }\end{array}$ & $\begin{array}{l}\text { ADT } \\
\text { (PCU) }\end{array}$ & $\begin{array}{l}\text { \% Share of } \\
\text { Traffic }\end{array}$ & $\begin{array}{l}\text { ADT } \\
\text { Vehicles }\end{array}$ & $\begin{array}{l}\text { ADT } \\
\text { (PCU) }\end{array}$ & $\begin{array}{l}\text { \% Share of } \\
\text { Traffic }\end{array}$ \\
\hline Two Wheeler & 898 & 449 & $16.6 \%$ & 329 & 164.5 & $10.6 \%$ \\
\hline Auto Rickshaw & 40 & 40 & $0.7 \%$ & 36 & 36 & $1.2 \%$ \\
\hline Car/Jeep/Van/Taxi & 1960 & 1961 & $36.2 \%$ & 1019 & 1019 & $32.7 \%$ \\
\hline Mini Bus & 24 & 36 & $0.4 \%$ & 18 & 28.5 & $0.6 \%$ \\
\hline Buses & 658 & 1974 & $12.2 \%$ & 259 & 780 & $8.3 \%$ \\
\hline Mini LCV & 366 & 366 & $6.8 \%$ & 212 & 212 & $6.8 \%$ \\
\hline LCV (4\&6 Tire) & 282 & 423 & $5.2 \%$ & 212 & 318 & $6.8 \%$ \\
\hline Truck (Two axle and Three Axle) & 887 & 2661 & $16.4 \%$ & 723 & 2169 & $23.2 \%$ \\
\hline Multi Axle Trucks (4 axles and more) & 145 & 652.5 & $2.7 \%$ & 204 & 918 & $6.6 \%$ \\
\hline HCM / EME & 3 & 13.5 & $0.1 \%$ & 5 & 22.5 & $0.2 \%$ \\
\hline Tractor & 40 & 60 & $0.7 \%$ & 12 & 18 & $0.4 \%$ \\
\hline Tractor + Trailer & 54 & 243 & $1.0 \%$ & 71 & 315 & $2.3 \%$ \\
\hline Cycles & 53 & 27 & $1.0 \%$ & 10 & 5 & $0.3 \%$ \\
\hline Cycle Rickshaw & 1 & 2 & $0.0 \%$ & 1 & 2 & $0.0 \%$ \\
\hline Animal Drawn Carts & 4 & 24 & $0.1 \%$ & 3 & 18 & $0.1 \%$ \\
\hline Total & 5414 & 8932 & $100.0 \%$ & 3112 & 6026 & $100.0 \%$ \\
\hline
\end{tabular}

\subsection{Seasonal Variations of Traffic Volume:}

Traffic levels along a study stretch vary during different periods of time i.e., in different months/seasons. Information on this aspect is necessary to estimate the AADT. This is best understood by studying monthly historical traffic volumes on the project corridor. This however is not available for the study stretch. In the absence of this direct information, it is customary to consider the monthly sales of petrol and diesel, at the fuel stations along the project corridor or on the road stretches in its environment. This information is presented in Table. The factors for passenger vehicles are based on petrol sales and that of goods vehicles (Trucks/LCV's) and buses on diesel sales.

Table 2 showing daily fuel sales and Seasonal Correction Factors (SCF) required estimating AADT

\begin{tabular}{|l|l|l|l|l|l|l|}
\hline & $\begin{array}{l}\text { Daily Diesel } \\
\text { Consumption (liters) }\end{array}$ & $\begin{array}{l}\text { Daily Petrol } \\
\text { Consumption (liters) }\end{array}$ & Both & $\begin{array}{l}\text { SCF } \\
\text { (Diesel) }\end{array}$ & $\begin{array}{l}\text { SCF } \\
\text { (petrol) }\end{array}$ & $\begin{array}{l}\text { SCF } \\
\text { (Both) }\end{array}$ \\
\hline April & 4654 & 396 & 5051 & 0.9 & 1.07 & 0.91 \\
\hline May & 4517 & 417 & 4933 & 0.93 & 1.01 & 0.94 \\
\hline June & 4289 & 400 & 4689 & 0.98 & 1.06 & 0.98 \\
\hline
\end{tabular}




\begin{tabular}{|l|l|l|l|l|l|l|} 
July & 3675 & 392 & 4067 & 1.14 & 1.08 & 1.14 \\
\hline August & 3325 & 364 & 3689 & 1.26 & 1.16 & 1.25 \\
\hline September & 3532 & 375 & 3907 & 1.19 & 1.13 & 1.18 \\
\hline October & 3771 & 437 & 4208 & 1.11 & 0.97 & 1.1 \\
\hline November & 4308 & 442 & 4750 & 0.97 & 0.96 & 0.97 \\
\hline December & 4474 & 444 & 4918 & 0.94 & 0.95 & 0.94 \\
\hline January & 4334 & 448 & 4782 & 0.97 & 0.94 & 0.97 \\
\hline February & 4769 & 473 & 5242 & 0.88 & 0.89 & 0.88 \\
\hline March & 4681 & 482 & 5162 & 0.9 & 0.88 & 0.89 \\
\hline Average & 4194 & 422 & 4616 & & \multicolumn{2}{|l}{} \\
\hline
\end{tabular}

Table-3 showing AADT obtained after applying Seasonal Correction Factors

\begin{tabular}{|l|l|l|l|l|}
\hline Survey Location & Nalavadi -159.500 & \multicolumn{2}{l|}{ Hallikeri-221.400 } \\
\hline Vehicle Category & ADT (PCU) & AADT & ADT (PCU) & AADT \\
\hline Two Wheeler & 449 & 395 & 164.5 & 147 \\
\hline Auto Rickshaw & 40 & 36 & 36 & 32 \\
\hline Car/Jeep/Van/Taxi & 1961 & 1727 & 1019 & 897 \\
\hline Mini Bus & 36 & 32 & 28.5 & 25 \\
\hline Buses & 1974 & 1739 & 780 & 686 \\
\hline Mini LCV & 366 & 322 & 212 & 186 \\
\hline LCV (4\&6 Tire) & 423 & 372 & 318 & 279 \\
\hline Truck (Two axle \& Three Axle) & 2661 & 2341 & 2169 & 1908 \\
\hline Multi Axle Trucks (4 axles and more) & 652.5 & 574 & 918 & 807 \\
\hline HCM / EME & 13.5 & 12 & 22.5 & 20 \\
\hline Tractor & 60 & 54 & 18 & 16 \\
\hline Tractor + Trailer & 243 & 214 & 315 & 277 \\
\hline Cycles & 27 & 27 & 5 & 4 \\
\hline Cycle Rickshaw & 2 & 2 & 2 & 2 \\
\hline Animal Drawn Carts & 24 & 24 & 18 & 18 \\
\hline Total & 8932 & 7869 & 6026 & 5305 \\
\hline
\end{tabular}

\section{TRAFFIC GROWTH RATES}

To establish the future traffic growth rates, following approaches have been explored.

- Past trends in Traffic growth on the Project Road.

- Growth of registered motor vehicles.

- Transport demand elasticity approach.

\subsection{Growth Rate based on Past Traffic Data:}

Past traffic data as collected from PWD is available for two locations (near Annigere and Gadag) along the project corridor. These data are available from January to July months of last 10 years. The growth rates were worked out for various categories of vehicles and conclusions were drawn.

Non-Uniformity in past traffic data of PWD may be attributed to errors during collection and processing of data and policy measures of the Government and other influences etc. To illustrate this point during recent years some of the mining activities around the project corridor have been banned by the Government which has caused a substantial decrease in the amount of trucks and Lorries. As the past traffic data on the Project Road is not showing any definite trend, one should not be guided by past traffic data for deriving growth rates.

\subsection{Growth Rate based on Vehicle Registration:}

An alternative approach is to explore the registered motor vehicles growth in the influence area and assume a growth rate equal to the average growth of vehicle registration. Such an assumption may not be correct, unless the area of influence is well defined and the general development pattern of influence area remains same. The growth rates for various modes are estimated and presented in Table-4, Growth of Registered Motor Vehicles in Karnataka. It can be observed from the above Table, during the last 7 years, average growth of two wheelers, cars and that of trucks is around $11 \%-12 \%$. This high growth rate of more than $10 \%$ may not sustain in future. Therefore other rational approaches were explored in order to derive realistic growth rates. 
Table 4 - Summary of Cumulative Average Annual Growth Rate of Vehicles (\%) in Karnataka state

\begin{tabular}{|l|l|l|l|l|l|}
\hline Year & Goods Vehicles & Buses & Cars/Jeep/Taxi & Two Wheelers & Three Wheelers \\
\hline $2004-2005$ & 221913 & 89294 & 841846 & 3957762 & 284078 \\
\hline $2005-2006$ & 276013 & 95627 & 958300 & 4512910 & 307862 \\
\hline $2006-2007$ & 312272 & 99202 & 1030629 & 3755719 & 359920 \\
\hline $2007-2008$ & 344764 & 110558 & 1209431 & 4230864 & 403910 \\
\hline $2008-2009$ & 366597 & 115016 & 1326395 & 4796587 & 364781 \\
\hline $2009-2010$ & 377495 & 159377 & 1398221 & 6404905 & 349729 \\
\hline $2010-2011$ & 415491 & 167087 & 1561131 & 7033045 & 440368 \\
\hline CAAGR in \% & $11.22 \%$ & $11.62 \%$ & $10.91 \%$ & $11.10 \%$ & $8.27 \%$ \\
\hline
\end{tabular}

Source: Ministry of Road Transport \& Highways Government of India (MoRT\&H)

\subsection{Traffic Growth Estimation by Transport Demand}

\section{elasticity Method:}

The exercise of traffic growth rate estimation has been carried out by us using the elasticity approach. The elasticity method relates traffic growth to changes in the related economic parameters. According to IRC-108-1996, elasticity based econometric model for highway projects could be derived in the following form:

$$
\log \mathrm{e}(\mathrm{P})=\mathrm{A} 0+\mathrm{A} 1 \log \mathrm{e}(\mathrm{EI})
$$

Where:

- $\mathrm{P} \quad=$ Traffic volume (of any vehicle type)

- $\mathrm{EI}=$ Economic Indicator (GDP/NSDP/Population/PCI)

- $\mathrm{A} 0=$ Regression constant;

- A1 = Regression co-efficient (Elasticity Index)

The main steps followed are:

- Defining the Project Influence Area from OD analysis of travel pattern.
- Estimating the past elasticity of traffic growth from time series of registered vehicles of influencing states.

- Assessment of future elasticity values for major vehicle groups, namely, cars, buses and trucks.

\subsection{Project Influence Area}

The results obtained from the Origin Destination surveys were used to identify the project influence area. The ratio of the total traffic originated/destined to a particular zone to the total traffic gives the influence factor for the particular zone. The influence factors were developed from the OD matrices and influence of each State is given in Table5. A comparative study of the influence factors indicated that Karnataka State, where the project stretch runs has the majority influence of ninety two percent (92\%). State of Goa, Andhra Pradesh and Maharashtra that has its border abutting Karnataka State has an influence factor of two percent $(2 \%)$ our percent $(4 \%)$ and two percent $(2 \%)$ respectively. Tamil $\mathrm{Nadu} / \mathrm{Kerala}$ and Rest of India has minimal or no share at all. These factors have all been accounted in derivation of the combined growth factor and utilized for the project sections.

Table -5 Influence of Vehicles observed on the Project Road

\begin{tabular}{|l|l|l|l|l|}
\hline States & Cars & Buses & Truck & Average \\
\hline Karnataka & $97.0 \%$ & $93.9 \%$ & $86.4 \%$ & $92.4 \%$ \\
\hline Goa & $1.3 \%$ & $0.5 \%$ & $3.7 \%$ & $1.8 \%$ \\
\hline Andhra Pradesh & $1.1 \%$ & $3.7 \%$ & $6.6 \%$ & $3.8 \%$ \\
\hline Maharashtra & $0.6 \%$ & $1.9 \%$ & $2.7 \%$ & $1.7 \%$ \\
\hline Rest of India & $0.0 \%$ & $0.0 \%$ & $0.7 \%$ & $0.2 \%$ \\
\hline Total & $100.0 \%$ & $100.0 \%$ & $100.0 \%$ & $100.0 \%$ \\
\hline
\end{tabular}

\subsection{Elasticity Values}

Elasticity value is the factor by which the socio-economic growth rate is multiplied to get the growth rate of traffic.
Traffic is directly linked to the economic growth such as percapita income, population and NSDP/GDP. Considering the time series data on category wise registered vehicles and the 
economic variables, by regression analysis elasticity values is

estimated as shown in Table-6

Table-6 Elasticity Values derived based on Regression Analysis for Karnataka State

\begin{tabular}{|l|l|l|l|l|}
\hline Mode & Variable & Elasticity & R square & $\begin{array}{l}\text { CAAGR } \\
\text { Registration) }\end{array}$ \\
\hline Two Wheelers & Per Capita Income & 2.86 & 0.80 & $11.10 \%$ \\
\hline Cars & Per Capita Income & 1.48 & 0.97 & $10.91 \%$ \\
\hline Buses & Per Capita Income & 1.45 & 0.75 & $11.62 \%$ \\
\hline Goods & NSDP & 1.23 & 0.97 & $11.22 \%$ \\
\hline Auto Rickshaw & Per Capita Income & 0.84 & 0.7 & $8.27 \%$ \\
\hline
\end{tabular}

Table-7 showing adopted Elasticity values for future years

\begin{tabular}{|l|l|l|l|l|l|}
\hline Mode & $\begin{array}{l}\text { Estimated Elasticity(2004- } \\
\text { 2011) }\end{array}$ & $\begin{array}{l}\text { Recommended } \\
\text { Elasticity }\end{array}$ & $2013-2018$ & $2018-2023$ & 2023 and Beyond \\
\hline Goods & 1.20 & 1.20 & 1.08 & 0.97 & 0.87 \\
\hline Buses & 1.45 & 1.20 & 1.08 & 0.97 & 0.87 \\
\hline Passenger Cars & 1.50 & 1.5 & 1.43 & 1.28 & 1.15 \\
\hline Two Wheelers & 2.86 & 1.6 & 1.52 & 1.37 & 1.23 \\
\hline Three Wheelers & 0.84 & 0.84 & 0.80 & 0.72 & 0.65 \\
\hline
\end{tabular}

\subsection{Traffic Growth Rates:}

Based on the moderated elasticity values and the projected economic/demographic indicators and with the given model as follows, the future average annual compound traffic growth rates by vehicle type are estimated.

\section{Passenger Vehicles:}

Traffic Growth Rate $=[(1+r p)(1+$ rpci $x$ Em $)-1]$
Where,

$\mathrm{rp}=$ Population Growth, $\mathrm{rpci}=$ Per capita Income Growth, Em= Elasticity

\section{Goods Vehicles:}

Growth Rate for Goods Vehicles = Elasticity Value * NSDP Growth Rate

The growth rate estimated form elasticity values are shown in the table below:

Table-8 Showing Growth Rates adopted for different classes of Vehicles

\begin{tabular}{|c|c|c|c|c|c|c|c|c|c|c|}
\hline \multicolumn{2}{|c|}{$\begin{array}{l}\text { Projected Traffic Growth } \\
\text { Rates adopted for the } \\
\text { Study }\end{array}$} & \multicolumn{3}{|c|}{ Pessimistic Approach } & \multicolumn{3}{|c|}{ Normal Approach } & \multicolumn{3}{|c|}{ Optimistic Approach } \\
\hline \multirow{2}{*}{$\begin{array}{l}\text { Sl. } \\
\text { No }\end{array}$} & \multirow[b]{2}{*}{ Vehicle Type } & \multicolumn{3}{|c|}{$\begin{array}{l}\text { Projected Annual Traffic Growth } \\
\text { Rate }(\%)\end{array}$} & \multicolumn{3}{|c|}{$\begin{array}{l}\text { Projected Annual } \\
\text { Growth Rate }(\%)\end{array}$} & \multicolumn{3}{|c|}{$\begin{array}{l}\text { Projected Annual } \\
\text { Growth Rate }(\%)\end{array}$} \\
\hline & & 2013-2018 & $\begin{array}{l}2018- \\
2023\end{array}$ & $\begin{array}{l}2023- \\
2023\end{array}$ & $\begin{array}{l}2013- \\
2018\end{array}$ & $\begin{array}{l}2018- \\
2023\end{array}$ & $\begin{array}{l}2023- \\
2023\end{array}$ & $\begin{array}{l}2013- \\
2018\end{array}$ & $\begin{array}{l}2018- \\
2023\end{array}$ & $\begin{array}{l}2023- \\
2023\end{array}$ \\
\hline 1 & LCV & $8.0 \%$ & $7.6 \%$ & $6.5 \%$ & $9.2 \%$ & $8.7 \%$ & $7.5 \%$ & $10.5 \%$ & $9.8 \%$ & $8.5 \%$ \\
\hline 2 & 2-Axle Truck & $4.9 \%$ & $4.6 \%$ & $3.9 \%$ & $5.6 \%$ & $5.3 \%$ & $4.5 \%$ & $6.4 \%$ & $6.0 \%$ & $5.2 \%$ \\
\hline 3 & 3-Axle Truck & $8.0 \%$ & $7.6 \%$ & $6.5 \%$ & $9.2 \%$ & $8.7 \%$ & $7.5 \%$ & $10.5 \%$ & $9.8 \%$ & $8.5 \%$ \\
\hline 4 & Multi-Axle Truck & $7.0 \%$ & $6.6 \%$ & $5.6 \%$ & $8.0 \%$ & $7.6 \%$ & $6.5 \%$ & $9.1 \%$ & $8.6 \%$ & $7.4 \%$ \\
\hline 5 & Bus & $6.8 \%$ & $6.6 \%$ & $5.7 \%$ & $7.9 \%$ & $7.6 \%$ & $6.6 \%$ & $9.0 \%$ & $8.5 \%$ & $7.4 \%$ \\
\hline
\end{tabular}




\begin{tabular}{|l|l|l|l|l|l|l|l|l|l|l|}
6 & Car & $8.5 \%$ & $8.3 \%$ & $7.1 \%$ & $10.0 \%$ & $9.6 \%$ & $8.3 \%$ & $11.4 \%$ & $10.9 \%$ & $9.4 \%$ \\
\hline 7 & Two Wheeler & $8.9 \%$ & $8.7 \%$ & $7.5 \%$ & $10.5 \%$ & $10.1 \%$ & $8.7 \%$ & $12.1 \%$ & $11.5 \%$ & $10.0 \%$ \\
\hline 8 & Auto Rickshaw & $5.2 \%$ & $5.1 \%$ & $4.4 \%$ & $6.0 \%$ & $5.8 \%$ & $5.0 \%$ & $6.8 \%$ & $6.5 \%$ & $5.6 \%$ \\
\hline
\end{tabular}

\section{DISCUSSIONS AND CONCLUSIONS:}

The comparison of growth rates on vehicular registration data and by elasticity value are as shown in the table below:

\begin{tabular}{|c|c|c|c|c|c|}
\hline \multicolumn{6}{|c|}{ Table-9 Comparison of Growth Rates by Various Methods } \\
\hline \multirow[t]{2}{*}{ Method } & \multicolumn{5}{|l|}{ Mode } \\
\hline & Two Wheeler & Car & Bus & Truck & Auto Rickshaw \\
\hline Past Traffic on Project Corridor & No trend & No trend & No trend & No trend & No trend \\
\hline $\begin{array}{l}\text { Vehicle Registration Growth of Karnataka } \\
\text { State }\end{array}$ & $11.10 \%$ & $10.91 \%$ & $11.62 \%$ & $11.22 \%$ & $8.27 \%$ \\
\hline Elasticity Method(2004-2011) & $10.50 \%$ & $10 \%$ & $7.90 \%$ & $8 \%$ & $6 \%$ \\
\hline
\end{tabular}

The growth rates obtained from transport demand elasticity method is being widely used method all over India. These growth rates are adopted to predict future traffic volumes and Laning Requirements.

\section{REFERENCES}

[1] L.R. Kadiyali \& T.V. Shashikala, "Road Transport Demand Forecast for 2000 AD Revisited and Demand Forecast for 2021" Journal of the IRC October December 2009 Paper No. 557

[2] Jahar R. Sarkar and Dr. Bhargab Maitra "Critical consideration of Travel Demand Forecasting on National Highways: A Case Study". IRC :Volume 62 No.3 2001

[3] Vijay Kumar, "Traffic Characteristics And Demand Along North and South Corridors- A Case Study", M.E. Thesis, Bangalore University, Bangalore March 2001.

[4] IRC: 102-1988, “Traffic Studies for Planning Bypass around towns"

[5] IRC:108-1996, "Guidelines for Traffic Predictions on Rural Highways"

[6] MORT\&H , Road Transport Year Book 2004-2007, 2007-2009, 2009-2011

[7] Reserve Bank of India Annual report. 